\title{
The resistance \& The Stubborn But Unsurprising Persistence of Hate and Extremism in the United States
}

Jeannine Bell

Indiana University Maurer School of Law, jeabell@indiana.edu

Follow this and additional works at: https://www.repository.law.indiana.edu/ijgls

Part of the Civil Rights and Discrimination Commons, Comparative and Foreign Law Commons, First Amendment Commons, Fourteenth Amendment Commons, Law and Race Commons, and the Legislation Commons

\section{Recommended Citation}

Bell, Jeannine (2019) "The resistance \& The Stubborn But Unsurprising Persistence of Hate and Extremism in the United States," Indiana Journal of Global Legal Studies: Vol. 26 : Iss. 1 , Article 9. Available at: https://www.repository.law.indiana.edu/ijgls/vol26/iss1/9

This Article is brought to you for free and open access by the Law School Journals at Digital Repository @ Maurer Law. It has been accepted for inclusion in Indiana Journal of Global Legal Studies by an authorized editor of Digital Repository @ Maurer Law. For more information, please contact rvaughan@indiana.edu.

\section{$\Psi$}

JEROME HALL LAW LIBRARY

INDIANA UNIVERSITY

Maurer School of Law
Bloomington 


\title{
The resistance \& The Stubborn But Unsurprising Persistence of Hate and Extremism in the United States
}

\author{
JEANNINE BELL*
}

\begin{abstract}
Though the far right has a long history in the United States, the presidential campaign and then election of Donald Trump brought the movement out of the shadows. This article will analyze the rise in White supremacist activity in the United States-from well-publicized mass actions like the White supremacist march in Charlottesville in August 2017 to individual acts of violence happening since November 2016. This article focuses on contextualizing such incidents within this contemporary period and argues that overt expressions of racism and racist violence are nothing new. The article closes with a call to strengthen the current legal remedies used to address bias-motivated violence.

The eight-year period between 2008 and 2016 has been a fascinating time for assessments of the state of race relations in America. After the election of Barack Obama, America's first Black ${ }^{1}$ president, commentators described the country as "post-racial." In a dramatic turn of events for a country that had transcended race just eight years later in 2016, Donald Trump's election as president was followed by a dramatic increase in the number of documented race-based hate

*Richard S. Melvin Professor of Law, Indiana University Maurer School of LawBloomington. J.D. University of Michigan-Ann Arbor, 1999; Ph.D. (Political Science) 2000; A.B. Harvard College-Cambridge, 1991. This article was presented at the Indiana Journal of Global Legal Studies Symposium. Sincere thanks to Rita Eads for secretarial assistance.

1. In this article the term "Black" is capitalized when it refers to African-Americans. See, e.g., Lori L. Tharps, The Case for Black With a Capital B, N.Y. Times, Nov. 18, 2014, https://www.nytimes.com/2014/11/19/opinion/the-case-for-black-with-a-capital-b.html (describing Oxford and Webster's dictionaries' statement that when referring to a group of people "Black" can be and frequently is capitalized).
\end{abstract}

Indiana Journal of Global Legal Studies Vol. 26 \#1 (Winter 2019)

(C) Indiana University Maurer School of Law 
crimes - crime motivated by bias on the basis of the target race.

The increase in reported hate crimes continued well into the Trump Administration's first year. What was most compelling about the new hate activity was the rise of a new, open presence of extremists-those ideologically committed to White supremacy. For decades, racial extremists - members of organized hate groups and others ideologically attached to the tenants of White supremacy-had lived in the shadows. After Trump's election, racial extremists stepped into the light.

This article grapples with the rise of racial extremist behaviorboth by ideologues who are part of hate groups and those who commit hate crimes seemingly randomly -in the wake of the 2016 presidential election. In this article, I explore the roots of bias-motivated activity that many found surprising in the election. I demonstrate how biasmotivated behavior has been part and parcel of recent American history. The article addresses not only the origins of such activity but also resistance to it and the capacity of American institutions created to address bias-motivated behavior. In the end, I argue that to effectively address extremist behavior, we must examine the seriousness of our societal commitment to racial separation.

\section{Part I. Setting the Stage for Racial Miasma}

Presidential candidate Donald Trump signaled support for racial extremists with anti-immigrant rhetoric targeted specifically at nonWhites. Though he had been surrounded by immigrants from the beginning (his mother emigrated from Scotland) and two of his wives, Ivana Trump and Melania Trump, immigrated to the United States, Trump attacked immigration from non-White countries. ${ }^{2}$ He called Mexican immigrants "rapists" who had brought crime into the United States and demanded "a total and complete shutdown of Muslims entering the United States." 3

On the campaign trail, Trump also criticized native-born, nonWhites who disagreed with him. After Mercution Southall, an African American Black Lives Matter activist, interrupted a Trump rally in Birmingham, Alabama, a bystander video was released depicting White attendees kicking and punching Southall while he was on the ground. ${ }^{4}$

2. Darran Simon, President Trump's Other Insensitive Comments on Race and Ethnicity, CNN, https:/www.cnn.com/2018/01/11/politics/president-trump-racial-comm ents-tweets/index.html (last updated Jan. 13, 2018).

3. $I d$.

4. Gabrielle Levy, Nostalgic for 'Old Days,' Trump Wants to Punch Protester in the Face', U.S. NEws \& WORLD REPORT (Feb. 23, 2016, 11:16 AM), https:/www.usnews.com 
The following day, in a direct invocation of the violent legacy of White supremacy, Trump appeared on Fox News and responded to the attack on Southall by saying, "Maybe he should have been roughed up, because it was absolutely disgusting what he was doing." 5

During the presidential campaign, White supremacists responded to Trump's "dog whistle" by openly praising him. Prominent White supremacists like David Duke, former Grand Dragon of the Ku Klux Klan, endorsed Trump's candidacy. Trump did not immediately reject Duke's support. Candidate Trump also praised Southerners who were fighting the removal of a Confederate statue, a key rallying issue for many White supremacists. ${ }^{6}$

As could have been expected by their pre-election endorsement, organized White supremacists openly celebrated after the election. ${ }^{7}$ As they did, those in the American press began to publicize the "Alt-Right movement-a loose consortium of White nationalists, White supremacists, neo-Nazis, [and] men's rights activists. ..." 8 Though the groups that make up the Alt-Right may slightly differ in composition and ideology, the groups were united in the belief that Whites faced danger posed by immigration, multiculturalism, and political correctness. ${ }^{9}$ In one widely publicized event at an Alt-Right conference hosted by the National Policy Institute, two weeks after Trump's election in November 2016, Richard Spencer proclaimed to the gathering of attendees, "We willed Donald Trump into office, we made this dream our reality!" 10 The dream that was a core part of the AltRight vision was made crystal clear later in the address when Spencer shouted, "Hail Trump! Hail our people! Hail victory!"11 In response, several of the attendees raised their hands in Nazi salutes. 12

/news/articles/2016-02-23/nostalgic-for-old-days-trump-wants-to-punch-protester-in-theface.

5. Id. As could be expected, Trump denied any connection to the violence directed at counter protesters. What legally constitutes incitement to violence is beside the point. Instead, I am making a much subtler point that Trump's statements in the wake of racial violence are extremely bad for body politics.

6. Glenn Thrush \& Maggie Haberman, Trump Gives White Supremacists an Unequivocal Boost, N.Y. TiMES, (Aug. 15, 2017), https://www.nytimes.com/2017/08/15 /us/politics/trump-charlottesville-white-nationalists.html.

7. Sarah Posner, Radically Mainstream: Why the Alt-Right is Celebrating Trump's Win, Rolling STONE, (Nov. 28, 2016, 8:16 PM), https://www.rollingstone.com/politics /politics-features/radically-mainstream-why-the-alt-right-is-celebrating-trumps-win110791/.

8. Id.

9. $I d$.

10. $I d$

11. Id

12. Id. 
Unorganized extremists-individuals unaffiliated with any White supremacist group-also celebrated Trump's victory. These "celebrations" involved more than just words or gestures. In the ten days following the election, the Southern Poverty Law Center (SPLC) which tracks bias-motivated incidents reported that there were roughly 900 reports of "hate crimes"-bias-motivated harassment and intimidation-occurring in cities across the United States. ${ }^{13}$ Though there were incidents of hate crimes before the election, many of the incidents that occurred in the wake of the election seemed a direct response, as harassers invoked Trump's name during assaults.

\section{PART II: THE NEW EXTREMIST “NORMAL”}

\section{A. Universities}

Since November of 2016, there has been a marked increase in the bias-motivated incidents occurring on college campuses. There are likely many causes for this phenomenon. First, there is the issue of targeting stemming from the fact that several extremist groups-Traditionalist Worker Party, Identity Evropa, American Renaissance, and Vanguard America - have specifically targeted college campuses. ${ }^{14}$

The reason for White supremacists' focus on college campuses was to use them to "force showdowns over free speech, generate more publicity and win over more adherents." 15 The environment of college campuses made it easy to do that. Schools consider themselves important spaces to disseminate ideas and even encourage debate about controversial issues. Extremist groups disseminated posters, stickers, and pamphlets, with slogans like "[t]ake back what is rightfully ours" or "[p]reserve your heritage, take up the fight," fomenting racial division

13. Ten Days After: Harassment and Intimidation in the Aftermath of the Election, SPLC (Nov. 29, 2016), https://www.splcenter.org/20161129/ten-days-after-harassmentand-intimidation-aftermath-election. Bias crimes are crimes motivated by the perpetrators bias on the basis of race, disability, religion, disability, or sexual orientation. Bias Crime Law and Legal Definition, USLEGAL, https://definitions.uslegal.com/b/biascrime/ (last visited Nov. 3, 2018).

14. Joe Heim, Hate Groups Make Unprecedented Push to Recruit on College Campuses, WASH. POST (Jan. 12, 2017) , https://www.washingtonpost.com/local/education/hategroups-make-unprecedented-push-to-recruit-on-college-campuses/2018/01/12/c66cf628e4f8-11e7-833f-155031558ff4_story.html?utm_term=.1930363f5a54 (noting that this push was a widespread effort, with one Anti-defamation league report finding that extremist organizations had spearheaded campaigns at more than two hundred college campuses and forty-two state campaigns).

15. Id. 
and encouraging White students to resist diversity. ${ }^{16}$

For extremists, college and university campuses are spaces tailormade for the particular type of publicity they need-broadcasting their message and attracting adherents to their cause. In the eyes of extremists, college campuses are "ideal for recruiting members and gaining publicity because [they are spaces where] the presence of hate groups inevitably creates an outcry. ..."17 The outcry does two thingsit allows like-minded students to know about the organization and also puts those who oppose it on notice. As Matthew Heimbach, the founder of the Traditionalist Worker Party, whose stated goal is to establish a Whites-only nation-state, put it, campaigning on colleges and university campuses lets the organization's foes:

...know that there are people that are radically opposed to them, that are afraid of them, that will challenge them. It shakes their thought that they've got the campus environment lockdown and lets them know that people who oppose them go to their school or are a part of their local community. ${ }^{18}$

At least according to Heimbach, many college students agreed with his organizations' message of white supremacy; Heimbach claimed that the organizations' membership tripled between 2017 and 2018 from 500 to 1,500 members. ${ }^{19}$

Part of the extremist group campaigns involved sponsoring controversial right-wing speakers on college campuses. Well-publicized events included the speeches by Milo Yiannapolis at the University of Washington, a speech by Ann Coulter at the University of California at Berkeley, and a speech by The Bell Curve author Charles Murray at Indiana University. Such events drew hundreds of counter protesters, required universities to spend thousands of dollars on police to protect students, and sometimes, as in the case of the Annapolis, resulted in injury.

The targeting of college campuses by extremist groups had a more long-lasting and insidious effect than the controversy that speakers and flyer campaigns generated. A report by the Anti-Defamation League (ADL) revealed that the number of racially charged incidents on college campuses has increased. The ADL counted 140 displays of racist activity from September 1 through December 18, 2017, a number that

16. $I d$.

17. $I d$.

18. $I d$.

19. Id. 
far exceeded the previous year when just 41 incidents were reported. ${ }^{20}$

Though most bias-motivated incidents on campus, like most hate crimes occurring outside of university settings, ${ }^{21}$ do not result in the victim's death, there are exceptions. For instance, Sean Urbanski, a White student at the University of Maryland, was charged with a hate crime committed against and murder of Richard Collins III. ${ }^{22}$ Collins, a Black senior at Bowie State University and second lieutenant in the Army was killed while visiting friends at the College Park campus. ${ }^{23}$ Urbanski, Collins murderer, was a member of a racist Facebook group called "Alt-Reich: Nation. ${ }^{24}$

\section{B. "Unite the Right" Comes to Charlottesville}

Given the drama that has attached to college campuses, the decision of several different organizations to rally in Charlottesville, Virginia, the home of the University of Virginia, in August 2017 was unsurprising. The Unite the Right rally was a Far-Right rally that occurred in Charlottesville, Virginia, from August 11 to 12, 2017. Its stated goal was to oppose the removal of a statue of Robert E. Lee from Emancipation Park.

Hundreds of extremists-neo-Nazis, KKK, and other members of the Far Right-gathered in Charlottesville. They were met by hundreds of counter protestors; one of whom, Heather Heyer, was killed when James Alex Field, who had White supremacist ties including marching in Charlottesville with the Vanguard America, drove his car into protestors. 25

After initially criticizing the violence by members of the Far Right, President Trump suggested that those on the Far Left had some blame for the violence that occurred. He lauded those who were in Charlottesville to protest the removal of Confederate statues and at one point compared the removal of a statue of Confederate General Stonewall Jackson to the removal of a statue of George Washington.

20. Id.

21. "Table 2, Incidents, Offenses, Victims, and Known Offenders by Offense Type,

2017." https:/ucr.fbi.gov/hate-crime/2017/tables/table-2.xls (showing 12 murders out of 7,175 incidents reported).

22. "Judge asked to postpone trial for man charged with hate crime in University of Maryland stabbing," BALTIMORE SUN, December 11, 2018, https:/www.baltimoresun.com/ news/maryland/crime/bs-md-urbanski-trial-postpone-20181211-story.html.

23. $I d$.

24. $I d$.

25. Jonah Engel Bromwich \& Alan Blinder, "What We Know About James Alex Fields, Driver Charged in Charlottesville Killing," N.Y. Times, Aug. 13, 2017, https://www. nytimes.com/2017/08/13/us/james-alex-fields-charlottesville-driver-.html. 
President Trump said, "This week, it is Robert E. Lee. And I notice that Stonewall Jackson is coming down. I wonder, is it George Washington next? And is it Thomas Jefferson the week after? You know, you have to ask yourself, where does it stop?" 26 Later, he noted that "there were very fine people on both sides." 27

\section{Explaining Charlottesville}

The events in Charlottesville were incredibly well-publicized, and the sheer visual effect of scores of young White men marching with torches was dramatic. These images mark a sharp contrast to how many Americans see themselves and view racial politics in this country. After all, in 2008, a Black president of the United States was elected with White voter support. At this event, many pundits labeled America "postracial."

The events in Charlottesville become less of an anachronistic anomaly when other issues that belie significant acceptance of racist rhetoric are considered. These incidents include racist tweets, a rise in the number of hate groups, and an increase in the number of hate crimes. According to a 2017 study, Twitter users who self-identify as White nationalists or neo-Nazis has grown 600 percent since 2012 .

The extremists who marched in Charlottesville did not come out of nowhere. In fact, the Southern Poverty Law Center, which has long tracked extremist groups, documented nearly eight hundred extremist groups in 2014 during President Obama's "post-racial" presidency. In 2015-a full year before the presidential election-the organization noted nearly nine hundred separate extremist groups.

There is also the issue of hate crimes. Since the presidential election in 2016, there has been an increase in the number of hate crimes. In fact, in 2016, as recorded by the FBI, the number of hate crimes reached a five-year high. ${ }^{28}$ That being said, the increase is not large. The number of single-bias incidents reported to the FBI in 2016 was $6,121-$ only about a 5 percent jump from $2015 .^{29}$ The takeaway point here is

26. Rosie Gray, Trump Defends White-Nationalist Protesters: 'Some Very Fine People on Both Sides', THE ATLANTIC, (Aug. 15, 2017) https:/www.theatlantic.com/politics /archive/2017/08/trump-defends-white-nationalist-protesters-some-very-fine-people-onboth-sides $/ 537012 /$.

27. Id.

28. See Hate Crimes, FBI, https:/www.fbi.gov/investigate/civil-rights/hate-crimes (last visited Oct. 5, 2018) (comparing the hate crime statistics from 2011 to 2015).

29. Id.; see also Richard Faussett, Rally by White Nationalists Was Over Almost Before It Began, N.Y. TIMES, (Aug. 12, 2018), https://www.nytimes.com/2018/08/12/us /politics/charlottesville-va-protest-unite-the-right.html (noting another hate crime study 
that though there have been increases in the number of hate crimes since the election, there were already large numbers of hate crimes being committed in the United States.

\section{PART III: ADDRESSING HATE VIOLENCE}

\section{A. The Response to Unite the Right}

The rapid and significant mobilization among extremists has not gone unaddressed. In fact, Americans of a variety of political persuasions resist being labeled racist. ${ }^{30}$ On university campuses, students have mounted organized resistance to conservative speakers. In some cases, this has led to violent clashes. In preparation for Charlottesville, anti-fascists, clergy members, and social justice activists mobilized and marched.

President Trump's statements expressing that the clashes at the Unite the Right rally in August 2017 had been caused by people on "both sides" were noteworthy because they stood in sharp contrast to the majority of the public comments surrounding the event. Even for those not "on the ground" protesting, there was significant condemnation of the racial extremists who marched in Charlottesville. This included condemnation of the violence by several members of Congress in a unanimous joint resolution. ${ }^{31}$

On the first anniversary of Charlottesville in August 2018, members of the Far Right gathered again to march, this time in Washington, D.C. The optics of the August 2018 march were quite different than the previous year. In 2018, despite significant publicity in the weeks leading up to the march, White supremacists were able to muster just two dozen individuals for the second Far Right rally. ${ }^{32}$ They were greatly outnumbered by counterprotesters and members of the news media. ${ }^{33}$

\section{B. Our general response to hate crime institutional inadequacy}

The response by counter-protesters to the second Unite the Right rally may suggest that America is well-poised to address the challenges posed by the extremism that has arisen in the wake of the 2016

conducted by the Center for the Study of Hate and Extremism suggesting that the number of hate crimes in 2016 were at the highest point in 12 years).

30. Jeannine Bell, There Are No Racists Here: the Rise of Racial Extremism, When No One is Racist, 20 MICH. J. RACE \& L. 349, 350 (2015).

31. S.J. Res. 49, 115th Cong. (2017).

32. See Fausset, supra note 27.

33. See id. 
presidential election. Unfortunately, other signs suggest that the opposite is true. Presently, this country is woefully unprepared to respond to even a moderate increase in the number of hate crimes. There is certainly hate crime legislation on the books in the vast majority of states. ${ }^{34}$ There is also federal hate crime legislation: the James Byrd and Matthew Shepard Hate Crimes Act. ${ }^{35}$

Despite the presence of hate crime legislation that blankets the entire United States, sometimes there is simply not a viable remedy. This is because most hate crimes are prosecuted at the state rather than the federal level. There are five states (Arkansas, Georgia, Indiana, South Carolina and Wyoming) that lack state hate crime legislation. ${ }^{36}$ In states without hate crime legislation, there is little incentive for law enforcement to investigate bias motivated crimes that are committed, but this does not mean that such incidents do not occur. ${ }^{37}$

Under the Hate Crime Statistics Act of 1990, police departments are required to report incidents that fit the pattern of hate crimes (irrespective of whether the state has a statute) to the FBI. ${ }^{38}$ Indiana is one of the states with the fewest number of hate crimes reported. 39 According to the Associated Press, between 2009 and 2014, more than half of Indiana's police agencies failed to report any hate crimes occurring in their jurisdiction to the FBI. ${ }^{40}$ Though the vast majority of jurisdictions have hate crime laws, 88.4 percent of police departments claimed that in an entire year, not a single hate crime was committed in their jurisdiction, according to the $2016 \mathrm{FBI}$ report. ${ }^{41}$

A good example of how the lack of a hate crime statute works on the

34. NAACP, StATe-BY-StATe HATE CRIMe LAws (2017), https://www.naacp.org/wpcontent/uploads/2017/09/Hate-Crimes-laws-by-state.pdf.

35. Hate Crime Acts, 18 U.S.C. $\$ 249$ (2012).

36. Audra D. S. Burch, "Spread of Hate Crimes Has Lawmakers Seeking Harsher Penalties," N.Y. Times, April 30, 2017, https://www.nytimes.com/2017/04/30/us/hatecrimes-legislation.html (identifying Arkansas, Indiana, Georgia, South Carolina and Wyoming as the 5 states that do not have any hate crime statutes).

37. Though Indiana has no hate crime legislation, police departments reported 55 hate crimes to the FBI in 2017. Police in all the other states without hate crime legislation nevertheless reported hate crimes occurring in their states in 2017 . The numbers of hate crimes were Arkansas: 7; Georgia: 27; South Carolina: 87; Wyoming; 4: FBI Hate Crime Statistics, 2017, Table 12: Agency Hate Crime Reporting by State, 2017, https://ucr.fbi.gov/hate-crime/2017/topic-pages/tables/table-12.xls.

38. Hate Crime Statistics Act of 1990, 28 U.S.C. $\$ 534$ (2012).

39. Half of Indiana police don't report hate crimes data to FBI, CHI. TRIB. (June 4, 2018, 11:26 PM), http:/www.chicagotribune.com/news/nationworld/midwest/ct-indianahate-crimes-20160604-story.html.

40. Id.

41. 2016 Hate Crime Statistics, FBI, https:/ucr.fbi.gov/hate-crime/2016/topicpages/jurisdiction (last visited Nov. 3, 2018) 
ground is to look at how police in Indiana treat bias-motivated incident. In Indiana, which has population of nearly three million people, law enforcement agencies reported only seventy-eight hate crimes occurring in 2016. ${ }^{42}$ Because Indiana does not have hate crime legislation, if the incident will not be prosecuted as a hate crime there is little incentive for victims even to report such incidents to the police.

In states without hate crime legislation or without law enforcement officers who investigate hate crimes, a cross burning is just a simple trespass case and not likely to be investigated by the police or prosecuted. Inspired by anti-immigrant and racist rhetoric, perpetrators continue their violent acts undeterred.

Even in states with hate crime legislation, there are numerous impediments to this being a viable remedy for those targeted by biasmotivated behavior. Police departments may be poorly trained in recognizing the incidents as hate crimes. Even if police do consider the incidence a hate crime and forward the files to the prosecutor's office, prosecutors may fail to charge hate crimes because of the perceived difficulty of making the charges stick. Assuming the case goes to trial, which is rare in the criminal justice system, there is the issue of getting such cases past juries. Given the FBI statisties and what hate crime scholars have noted, in race-based hate crimes, the typical perpetratorvictim configuration involves a White perpetrator and a minority victim. If hate crimes are anything like other serious crimes, White jurors may be reluctant to convict White perpetrators for crimes committed against victims of color.

\section{CONCLUSION}

Strong institutions-police who investigate, prosecutors who bring charges against hate crime perpetrators, judges and juries who convict and adequately sentence guilty offenders-are essential to providing a vigorous response to extremism. When viewed nationwide, American legal institutions - from our patchwork of hate crime laws to poorly trained police-are weak responses to dangerous extremists.

Unfortunately, our weak institution is not the worst of our problems. Though the weakness of our institutions may play an important role in the American failure to address hate crimes, there is an even more significant barrier to adequately addressing the danger posed by extremist violence - our national unwillingness to fully commit to the project of racial reconciliation. In a way, this project in both the

42. 2016 Hate Crime Statistics: Agency Hate Crime Reporting by State 2016, FBI, https:/ucr.fbi.gov/hate-crime/2016/tables/table-12 (last visited Nov. 3, 2018). 
Fourteenth Amendment, the bedrock of our notion of racial equality, and civil rights equal protection cases did not emerge as a result of any sort of populist uprising. Rather, the Fourteenth Amendment came out of a bloody civil war. The nation as a whole has never agreed to any promise of equality for marginalized people. Thus, the idea that marginalized people-racial and ethnic minorities - should not be subject to racial attacks because of their race is not something that the American populace has fully embraced.

The failure to understand the implications of marginalized people being subject to race-based attacks is clear in the First Amendment debate that frequently arises in the context of hate speech. American legal scholars who write in the area of the First Amendment are much more concerned about the government suppression of speech than the ideas in hate speech. The argument that denigrating speech leads to violence is something that Europeans, who have seen the dangers of extremism, understand and Americans do not. With respect to extremism, Americans are arrogant. We think we have got this. The rising level of extremism since November 2016 suggests we are wrong. 
